\title{
Situational Analysis of Primary Education in Mozambique
}

목 차

I. Introduction

II. Education System and Financing

1. Education Administration and Management

2. Financial resources

III. Access and Quality of Primary Education

1. Enrollment

2. School Retention

3. SDI Survey Result

4. Quality (Learning Outcome)

IV. Analysis of EMIS data

1. Overage rate

2. Dropout rate

3. Pass rate

4. Repetition rate

V. Conclusion

References 


\section{Abstract}

Since 2000, with the extensive support from international development organizations and policy interventions to remove access barriers on primary education, Mozambique experienced a rapid expansion in its education system. As access to education improved, the more children ever before attend schools; around 6 million students in primary education in 2015. Subsequently, net enrollment rates in primary education increased by 37.5 percent and, at the same time, gender disparity in access to education has declined from 0.79 to 0.95 . However, school enrollment in recent years became stagnant and learning outcome has deteriorated in regional and national exams.

In this paper, with the review of primary education system in Mozambique and biggest challenges of primary education with respect to access and quality of education, we examine the current situation of primary education in Mozambique using data from the Education Management Information System and present useful implications to development organizations in their future interventions.

Keywords: Primary education, quality education, EMIS, Mozambique 


\section{Introduction}

The right to an education is not just the right to attend school, but also to learn

essential knowledge and skills in order to progress and develop as individuals and as a society. In this regard, the estimated 57.6 million1) African children leaving school without proper knowledge and skills means a lost opportunity for the whole generation to reach their potential and escape poverty.

Since 2000, with the extensive support from international development organizations and various policy interventions-which were applied to remove barriers to educational access, along with other developing countries in Africa, Mozambique experienced a rapid expansion of its educational system. Access to education improved as more children entered primary school than ever before. From 1999 to 2015, there was a remarkable increase in primary net enrollment rates: 37.5 percent. Gender inequalities also have been eased - gender parity index (GPI), the ratio of female students to male students, has increased from 0.79 to 0.95 in primary education (UNESCO Institute of Statistics).

Despite the significant progress of raising primary school enrollment over the past decade, many formidable challenges in primary education system remain unsolved. The enrollment rate has become stagnant in recent years. Completing schooling is unlikely for many students, with the completion rate at $41 \%$ in 2011 , while the dropout rate is disturbingly high with an estimated 1.2 million children out of school. Furthermore, gender and geographical gaps in education outcomes has become wider.

Recent evidence revealed the deterioration of educational quality and learning outcomes. The National learning Assessment in 2013 demonstrated only 6.3\% of children in third grade have basic reading competencies. The Service Delivery Indicators (SDI) survey (World Bank, 2015) indicated only 1 percent of primary school teachers reached the minimum knowledge expectations for quality teaching

1) Brookings Institute, Learning Barometer 
and there are high levels of absenteeism from both teachers (45 percent) and school directors (44 percent), which is being reflected in the low learning outcomes of students.

Addressing these worsening problems in quality and access requires putting more resources in education. However, a further increase of the education budget is unlikely since the allocation of funding to the education budget from the total government budget and national income is already high. Furthermore, the recent fiscal crisis seems to continue without signs of improvement.

Recognizing the importance of the problems, we examine the current situation of primary education in Mozambique using the Education Management Information System (EMIS) data and statistics available and present useful information to those in development organizations with respect to future interventions. 


\section{Education System and Financing}

\section{Education administration and management}

In terms of overall management of the education system, the Ministry of Education

and Human Development (MINEDH) is taking a leading role in the responsibility

of planning, managing and monitoring. School curricula and programs are defined

by MINEDH through its National Institute for Educational Development (INDE).

Also, MINEDH establishes pedagogical guidelines and teaching programs, sets out rules and regulations for the recruitment, trains and manages teaching and nonteaching staff, and supervises and inspects teaching activities.

Although the key functions of an education administration are mostly centralized, some functions have been decentralized to sub-national levels, typically to the provinces, districts and schools themselves (Ribeiro, 2007). The schools take a key role inthe planning process of educational needs. This is mainly initiated from the bottom of the education system, where each school identifies material resources, financial resources for recurrent and capital expenditure, and teaching and non-teaching staff, etc.

At a provincial level, eleven Provincial Education Directorates (DPEJTs) supervise the overall administration of education. The DPEJTs follow and administer the educational policy and programs of MINEDH within their territorial areas. The Minister of Education, in close consultation with Provincial Governors, appoints the provincial directors. A District Education Office is playing a fundamental role in identifying educational needs in local communities. The provincial governor on the recommendation of the provincial director appoints district directors. School directors are appointed for each school, and are usually assisted by two deputy directors in pedagogical and administrative sections. 
〈Table 1〉 Structure of the Education System

\begin{tabular}{c|c|c|c|c}
\hline Ages & Grades & Terms & Category & Level \\
\hline $16 \sim 17$ & $11 \sim 12$ & 2 & Upper Secondary & $3^{\text {rd }}$ Level \\
\hline $13 \sim 15$ & $8 \sim 10$ & 3 & Lower Secondary & $2^{\text {nd }}$ Level \\
\hline $6 \sim 12$ & $1 \sim 7$ & 7 & Primary & $1^{\text {st }}$ Level \\
\hline $1-5$ & - & - & Pre-School- & - \\
\hline
\end{tabular}

Source: MINEDH homepage: http://www.mec.gov.mz/EDUCA/Pages/default.aspx (accessed on May $\left.3^{\text {th }}, 2017\right)$

\section{A. Pre-school education}

Pre-school education is not compulsory nor is it free in Mozambique. Most preschool programs are provided at nurseries and kindergartens for children who are aged less than 6 years. Unlike other types of schoolings, pre-school education is coordinated among different government ministries (the Ministry of Education, the ministries of Women and Social Action and of Health). These related ministries define the general rules and guidelines for supervision of preschool education, while also supporting and monitoring their implementation. 40,000 children aged less than 6 years old in 2005 are estimated to have received some form of preschool education, which is less than $1 \%$ of the corresponding age group (UNESCO, 2012).

\section{B. Primary education}

Primary education consists of seven years, subdivided into two levels: the first level (EP1) covers grades from 1 to 5, and second level (EP2), grades 6 and 7. Primary education is compulsory and the official school entry age is 6 years old. The main aim of primary education is to provide basic knowledge and skills in the areas of communication, mathematics, natural and social sciences, and physical, aesthetic and cultural education. Since2004, a new basic education curriculum has been developed and introduced, which is marked by the introduction of two sub-cycles in EP1 (grades 1 and 2, and grade 3 to 5), and the introduction of local languages in early primary grades.

The progression to the next grade in EP1 is based on the decision of the class 
teacher, whom takes the student's attendance and assessment records into consideration. Each EP1 students possesses an assessment record, which is the main median in communicating between their parents and the school. At the end of each primary education level (grade 5 and grade 7 ), students take a national exam to gain access to further education (UNESCO, 2012).

제 I 장 and the other is the upper secondary for the remaining two years (grades 11 and 12). In addition to general education, technical schools provide technical and vocational education and training (TVET) programs in different fields such as agriculture, industry and business.

\section{Higher education}

Mozambique developed a separate law for higher education, with which tertiary-level and higher education institutions offer a variety of programs, ranging from a bachelor's degree (three-year program) to a licentiate degree (normally, a four-year program), to a master's degree (two-year program).

\section{E. Teacher Training}

Primary teachers in Mozambique have a diverse set of qualifications because many have trained in different programs and with different models, partially due to a need to ease the acute staffing shortage. In 2007, a model for primary school teachers was introduced, where teacher-training institutes (IFP) operate two-year training programs for $10^{\text {th }}$ grade graduates but it has not been rolled out and one-year training program is still dominant teacher training program. For lower secondary education teachers, a one-year program is provided for $12^{\text {th }}$ grade graduate. The curriculum for primary school teachers' training program encompasses five categories: social sciences, educational sciences, communication, expression, and 
working activities, mathematics and natural sciences.

\section{Financial resources}

In order to meet the increasing enrollments in primary education, the government of Mozambique has sustained a larger budget for higher-level education from the total governmental budget and national Gross Domestic Product (GDP). There has also been new policy interventions introduced to lower school entry barriers, such as abolishing school fees (World Bank, 2009a).

Throughout 2008 until 2014, the education sector grew faster than the country's economy. The education expenditure to the GDP increased from 5.4 percent to 7.0 percent, which is higher than that of both low-income countries (4.3\%) and sub-Saharan African countries (3.9\%). It is also notable that it surpassed the United Nations Educational, Scientific and Cultural Organization (UNESCO) recommendation of $6.0 \%$. Furthermore, the percentage of education expenditure to total government budget $(19.4 \%)$ is higher than that of its income peers $(16.7 \%)$.

Domestic resources accounted for $88 \%$ of the educational budget, with 12\% coming from external development partners (i.e. donor agencies). Their assistance has focused on investment programs (such as infrastructure, teacher training, textbooks, etc.). In 2016, donors were responsible for providing 78\% of investment resources spent on education (UNICEF, 2017). On the other hand, the largest share of the governmental budget is used for recurrent expenses, such as teacher salaries.

In the sub-sectors, primary education accounts for $53 \%$ of the educational budget, followed by secondary education and administration development as $27 \%$ and $17 \%$ respectively. 


\section{Access and Quality of Primary Education}

\section{Enrollment}

Along with international efforts in pursuit of universal primary education set by the Millennium Development Goals (MDGs), and Education for All (EFA) initiative, the government of Mozambique has strived to ensure access to education by abolishing school fees, providing free textbooks, and recruiting more teachers to meet rising enrollment. As a result of these efforts, from 1999 to 2015, enrollment has increased almost three times over, from 2.3 million to 5.9 million, which means 3.6 million new children have had access to primary education ( $<$ Figure $1>$ ).

Access to education has improved, and thus more children are entering school. Net enrollment rates of primary education dramatically increased by $37.5 \%$ from 1999 (51.7percent) to 2015 (89.1 percent). During this same time period, gender inequality also has been eased. Gender Parity Index (GPI), the ratio of female student to male students, has increased from 0.79 to 0.95 in primary education, meaning almost as many female students are in school as male students $(<$ Figure $1>$ ).

〈Figure 1〉 Net Enrollment and Net Enrollment Rate in Primary Education

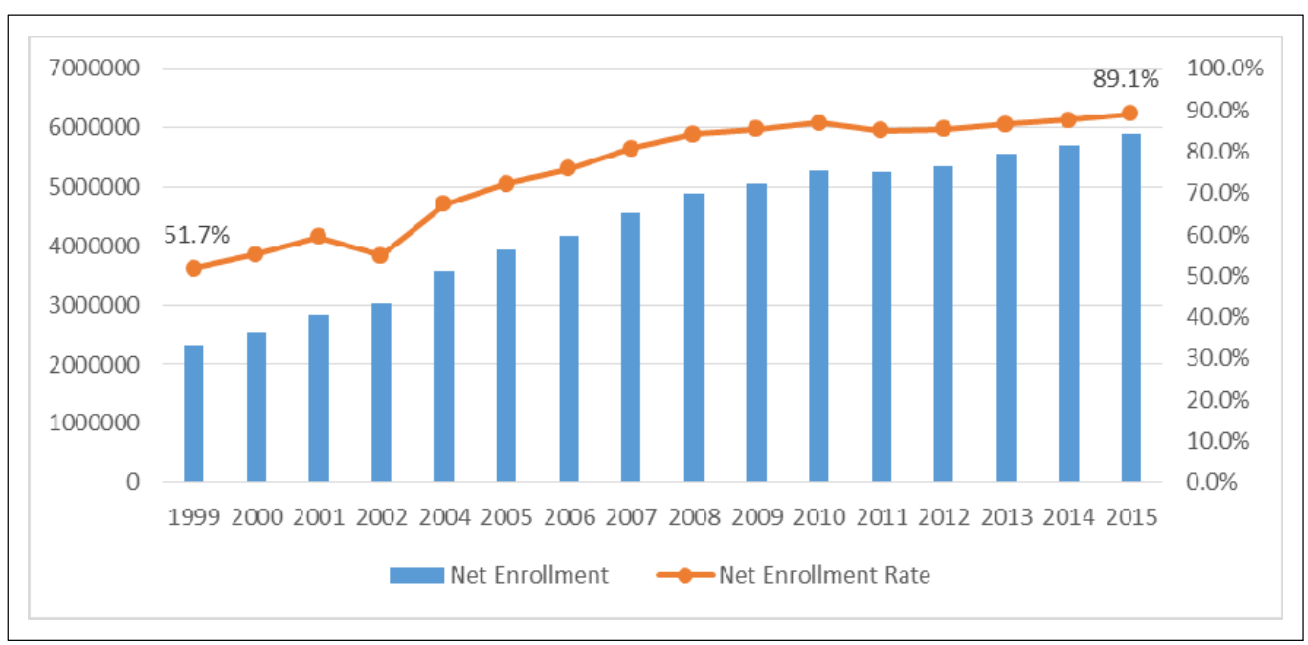

Source: UNESCO Institute for Statistics (UIS) (accessed on May $3^{\text {rd }}, 2017$ ) 
These enrollment successes of primary education, however, are counteracted by persistent low completion and low learning outcomes. Primary completion rates have stagnated at around 47 percent over the past few years, due to high dropout rates in primary education. Consequently, Mozambique lags behind the regional average by 19 percentage points.

Furthermore, 24 percent of official primary school aged students (1.2 million) are out of school. Approximately 25 percent of primary school aged boys are out of school compared to 24 percent of same aged girls. Socio-economic status and whether they live in rural areas both affect the probability of being out of school. Children from rural areas are twice as likely to be out of school as their counterparts (EPDC, 2014). The high level of initial enrollment is encouraging but nevertheless the educational institutions and systems are failing to retain the students in the long term.

\section{School Retention}

Keeping students in school is as important as enrolling students in school. However, Mozambique has suffered from a lower level of retention than other countries. The transition rate for EP1 to EP2 has been staggering around 60 to 70 percent with a gradual decline in recent years, while the number of grade 5 students has grown in celerity. About 29 percent of children who complete EP1 have no chance to continue their studies due to the shortage of teachers, and the shortage of safe classrooms (UNESCO, 2012).

The combined effects of the dropout and repetition rates during school years undermine the level of retention. The Demographic Household Survey (DHS) 2011 estimated the completion rate and survival rate to grade 5 as 41.5 percent and 49.7 percent respectively. 
$\left\langle\right.$ Figure 2〉 Survival Rate to Primary Education (to $7^{\text {th }}$ Grade)

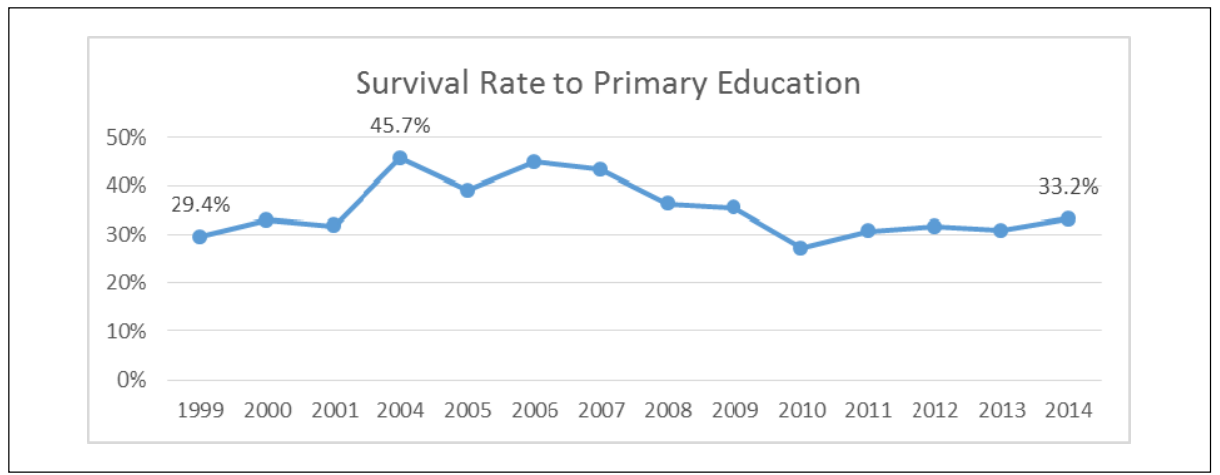

Source: UNESCO Institute for Statistics (UIS) (accessed on May $3^{\text {rd }}, 2017$ )

제 I 장

제II 장

섹

터

포

커

스

$<$ Figure $2>$ describes the dropout rates of primary education over years. Initial rapid increase occurs from 1999 (29.4\%) to 2004 (45.7\%), and then it goes down to $33.2 \%$ in 2014 for almost 10 years. More than 10 percent of cohort students leave school every year and only three in ten students who start school at the same year can reach $7^{\text {th }}$ grade in EP2.

\section{SDI Survey2)}

In 2014, the World Bank, collecting data from 200 primary schools, 1,006 teachers, and 1,731 grade four children, conducted the SDI survey in Mozambique. The report highlights the striking contrast of education inputs and its outcomes. Basic teaching and learning inputs are relatively accessible in schools, compared to other SDI countries.

However, time for teaching and learning was unduly short, caused by high level of teacher absenteeism: 45 percent of teachers were not in school and a further 11 percent of teachers were at school but not engaged in teaching. Teachers are twice as likely to be absent as their school directors. Lack of teacher's capacity for teaching is serous in its multitude. The average teacher score on three subjects - Portuguese, mathematics, and pedagogy was only 29 percent.

2) The Service Delivery Indicators (SDI) provides a set of metrics for benchmarking service delivery performance in education and health in Africa. Refer to http://siteresources.worldbank.org/AFRICAEXT/ Resources/What_is_SDI.pdf (accessed on May $7^{\text {th }}$ 2017) 
The SDI report, also, found a high level of absenteeism among students. 56 percent of students were absent on the school visit. Not surprisingly, learning outcomes were low. The grade 4 students in Mozambique ranked the lowest in their educational performance compared to other SDI countries, scoring 24 percent $(<$ Table 2$\rangle)$. The relation between student performance and teacher absenteeism and capacity was obvious. The best performing schools tended to have teachers with 17 percent more knowledge and were 30 percent less likely to be absent.

〈Table 2〉 SDI Education Indicators

\begin{tabular}{l|c|c}
\multicolumn{1}{c|}{ Indicators } & Mozambique & $\begin{array}{c}\text { Average of Other SD } \\
\text { countries }{ }^{3}\end{array}$ \\
\hline Student Test Score (\%) (math, language) & 24 & 52.8 \\
\hline Student Mathematics Test & 26 & 52.4 \\
\hline Student Language Test & 23 & 52.2 \\
\hline Teacher Minimum knowledge (\%) & 1 & 17.2 \\
\hline Teacher Test Score (\%) & 29 & 44 \\
\hline School absence rate (Teacher) & 45 & 17.8 \\
\hline Class absence rate (Teacher) & 56 & 40.2 \\
\hline Director absence rate & 44 & $\mathrm{NA}$ \\
\hline Teaching hours per day & $1 \mathrm{hr} 41 \mathrm{~min}$ & $3 \mathrm{hr} 7 \mathrm{~min}$ \\
\hline Share of students with textbooks & 69 & 41.6 \\
\hline Equipment availability (\%) & 74 & 65.2 \\
\hline Infrastructure availability (\%) & 27 & 40 \\
\hline
\end{tabular}

Source: World Bank (2015)

\section{Quality (Educational Achievement)}

Since 2000, Mozambique has participated in the Southern and Eastern African Consortium for Monitoring Educational Quality (SACMEQ) project, which measures the achievement levels of grade 6 students in reading and mathematics. From SACMEQ II in 2000, Mozambique achieved 516.7 for reading and 530 for math,

3) Kenya, Nigeria, Tanzania (round2), Togo, Uganda 
slightly higher than the SACMEQ average (500). The variation among the regions was considerable, in both subjects. Maputo City scored the highest with 549.1 for reading and 546.5 for mathematics, while Niassa in the north and rural region was placed on the bottom as 453.8 for reading and 488.2 for mathematics.

In the following SACMEQ III in 2007, the worrisome deterioration trend both in literacy and numeracy competence of grade 6 students was identified. The reading score and mathematics scores dropped by 41 percent and 46 percent respectively comparing the previous test in 2000. Almost a fourth (21.5 percent) and a third (32.8 percent) of grade 6 students failed to reach basic reading and numeracy skill levels respectively, which was a dramatic decline from the 2000 results. At the same time, inequality (variation) of test scores across provinces worsened ( $<$ Table $3>$ ).

〈Table 3〉 SACMEQ Students Learning Achievement 2000 and 2007

\begin{tabular}{|c|c|c|c|c|c|c|}
\hline \multirow{2}{*}{ Province } & \multicolumn{3}{|c|}{ Reading Score } & \multicolumn{3}{|c|}{ Mathematics Score } \\
\hline & 2000 & 2007 & Change & 2000 & 2007 & Change \\
\hline Cabo Delgado & 460 & 448 & $\downarrow$ & 498 & 460 & $\downarrow$ \\
\hline Caza & 504 & 487 & $\downarrow$ & 526 & 504 & $\downarrow$ \\
\hline Inhambane & 508 & 498 & $\downarrow$ & 541 & 506 & $\downarrow$ \\
\hline Maputo City & 549 & 540 & $\downarrow$ & 547 & 512 & $\downarrow$ \\
\hline Manica & 512 & 466 & $\downarrow$ & 543 & 483 & $\downarrow$ \\
\hline Maputo & 530 & 511 & $\downarrow$ & 535 & 509 & $\downarrow$ \\
\hline Nampula & 534 & 461 & $\downarrow$ & 539 & 472 & $\downarrow$ \\
\hline Niassa & 454 & 441 & $\downarrow$ & 488 & 445 & $\downarrow$ \\
\hline Sofala & 513 & 454 & $\downarrow$ & 523 & 472 & $\downarrow$ \\
\hline Tete & 488 & 427 & $\downarrow$ & 511 & 455 & $\downarrow$ \\
\hline Zambezia & 514 & 470 & $\downarrow$ & 517 & 478 & $\downarrow$ \\
\hline Mozambique & 517 & 476 & $\downarrow$ & 530 & 484 & $\downarrow$ \\
\hline SACMEQ & 500 & 512 & & 500 & 510 & \\
\hline
\end{tabular}

Source: SACMEQ Project III retrieved from http://www.sacmeq.org (accessed on May $5^{\text {th }}, 2017$ )

$<$ Table $3>$ indicates that there is a wide difference in student achievement levels across the 11 provinces of Mozambique in 2007 and all provinces experienced a decline in pupil reading and mathematics performance. This implies that there was an overall deterioration in the academic performance of grade 6 student sduring these 
years. SACMEQ III suggests the decline of student learning outcome is a probable tradeoff of rapid expansion of the education system during the years.

As described above, ensuring enrollment is not a necessary condition for educational success. Within the current education system, Mozambique meets the situation where more boys and girls are entering primary school but leaving without basic skills such as reading and math.

In 2013, Mozambique introduced the first national learning assessment for reading. The results confirmed that students were learning very little. Only 6.3 percent of grade 3 students achieved basic reading competencies (UNICEF, 2014). 


\section{Analysis of EMIS data}

Every year the Ministry of Education (MINEDH) in Mozambique collects education administrative data from school levels all over the country and stores the data in the Education Management Information System (EMIS). The data includes three kinds of information: school information (such as types and levels of school and geo-location: province and district), teacher information (such as gender and qualification), and student information (such as age, gender and status of enrollment, and so on).

제 I 장

After collecting data, the Ministry of Education publishes two books of Education Statistics: one is annual school survey, the other is annual school result in every August. Using the data and statistics in 2015, this section examines and analyzes the key educational indicators: dropout rate, overage rate, repetition rate, and pass rate.

\section{Overage rate}

Overage is traditionally considered a precursor of poor education outcomes such as a high dropout rate, lower promotion rate and lower academic achievement rates (Schulz et al., 1986). The overage rate can be caused by late enrollment in grade 1 (initial overage) and amplified by continued repetition and re $\mathrm{e}^{-}$entry to school. In many developing countries, high overage rates in primary education are a pervasive phenomenon, posing a significant obstacle to further educational progress.

The number of children entering grade 1 at the official entry age is manifestly low. There is a significant number of older children enrolled in the same grade, which shows the prevalence of late entry into primary education. The situation reflects both the lack of legal mechanisms and the inability of the school network to accommodate all the children aged 6 (UNESCO, 2012). 
〈Table 4〉 Overage across Provinces

\begin{tabular}{c|c|c|c}
\hline \multirow{2}{*}{ Province } & \multicolumn{3}{|c}{ Overage (\%) } \\
\cline { 2 - 4 } & Male & Female & Total \\
\hline Cabo Delgado & 57.31 & 54.04 & 55.68 \\
\hline Nampula & 55.35 & 51.97 & 53.66 \\
\hline Zambézia & 48.14 & 45.84 & 46.99 \\
\hline Niassa & 48.71 & 44.29 & 46.5 \\
\hline Manica & 48.33 & 42.72 & 45.52 \\
\hline Tete & 44.17 & 38.94 & 41.55 \\
\hline Sofala & 41.76 & 38.94 & 40.35 \\
\hline Gaza & 43.53 & 34.3 & 38.91 \\
\hline Inhambane & 39.96 & 31.73 & 35.84 \\
\hline Maputo & 34.51 & 27.07 & 30.79 \\
\hline Maputo City & 25.17 & 19.11 & 22.14 \\
\hline
\end{tabular}

Source: MINEDH (2015)

Although the overage rate for a grade is defined as a percentage of students who are one or more years older than the official grade-appropriate age, we defined overage rate more generously: as the percentage of students who are two or more years older than grade-appropriate age allowing for the possible mistakes over the course of school enrollment process.

Overage rates in primary education are strikingly high in Mozambique. The national mean is 44 percent. Geographically, northern regions have higher overage rates, while southern regions has much lower ones. Nearly 60 percent of students in Cabo Delgado and Nampula are overage. On the other hand, only 30 percent of students in the Maputo City, Maputo, Gaza, and Inhambane provinces are overage $(<$ Table $4>)$.

Intriguingly, female students are less likely to be overage. The difference of overage rates between males and females starts at 1 percent point in grade 1 but ends up around 10 percent points at the end of primary education. In other words, female students enroll in school as late as males, but females are less likely to repeat a grade and more likely to progress to the next grade $(<$ Figure $3>$ ). 
〈Figure 3〉 Overage rates in Primary Education

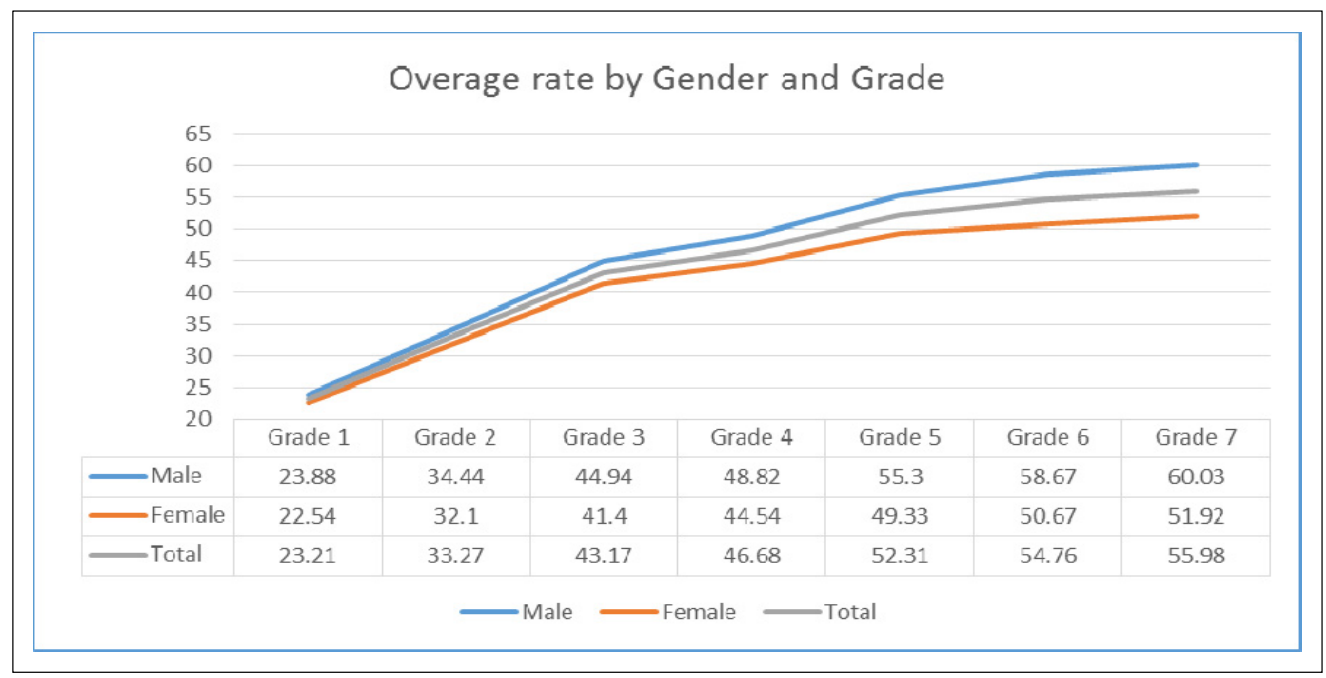

Source: MINEDH (2015)

The overage rate exaggerates over grades, due to a large number of students repeating grades. Starting from 23 percent at grade 1, overage rates ascend up to 56 percent by grade 7 . Overage rates increase more rapidly during grade 1 to 3 than during grade 4 to 7 . Overage rates in grade 1 can be explained by a large number of initial late enrollments and the increase of overage rates in subsequent grades can be attributed to high repetition occurred from the previous years.

Geographically, southern and urban areas - Maputo City and Maputo province - have distinctive patterns of overage students in each grade. In these two regions, overage increases constantly regardless of grade. A possible explanation is that many children flows into these areas with economic opportunities and better social infrastructures. This is confirmed by the negative dropout rate (net-inflow) in some schools within the two areas. Many of the students moved from rural areas during school years often end up stopping their education or enroll school in the next year.

Inference of high overage rates to educational attainment and achievement is apparent as literatures confirm that overage rates are closely intertwined with lower education attainment or achievement. Given the extreme level of overage students in Mozambique, it will be an arduous journey for Mozambique to improve education 
attainment and achievement without addressing the overage issues in primary education.

\section{Dropout rate4)}

High dropout rates are one of the most serious problems of primary education in Mozambique. In 2015, the national average was 11.2 percent for a grade. Given 5.8 million of total students are in primary education, it is estimated around 600,000 students left school in 2015, which is huge waste of financial resources and an enormous loss of future human resources. According to UNESCO Institute for Statistics (UIS), Mozambique places as having the second lowest survival rate to grade 5 three consecutive years from 2012 to 2014. More than half of students who started school fail to reach grade $5(<$ Table $5>$ ).

〈Table 5〉 Survival Rate to Grade 5

\begin{tabular}{c|c|c|c|c}
\hline \multicolumn{5}{c}{ Survival Rate to Grade 5 } \\
\hline Year & 2004 & 2012 & 2013 & 2014 \\
\hline Mozambique & 62.4 & 50.1 & 48.4 & 49.7 \\
\hline World & 84.69 & 85.18 & 87.24 & 87.10 \\
\hline
\end{tabular}

Source: UNESCO UIS data retrieved from http://data.uis.unesco.org (accessed on April $8^{\text {th }}, 2017$ )

From a gender perspective, there is no significant difference in dropout rates between males and females ( $<$ Table $6>$ ). The mean dropout rate is 9.88 percent for females and 10.62 percent for males. The dropout issues in Mozambique bear hard both on females and male.

However, there are huge inequalities of dropout rates between the geographic regions. The northern region has the highest level of dropout, such as the 16 percent for Niassa province, whereas the southern regions have much lower rates, and relatively moderate levels, such as the 3 percent rate for Maputo City.

4) MINEDH defines dropout rates as percentage of student leave school during a given academic year. 
〈Table 6〉 Dropout Rate by Gender and Province

\begin{tabular}{c|c|c}
\hline Province & Female & Male \\
\hline Niassa & 16.42 & 16.87 \\
\hline Cabo Delgado & 12.74 & 14.18 \\
\hline Sofala & 11.14 & 10.75 \\
\hline Tete & 11.70 & 11.97 \\
\hline Nampula & 11.00 & 12.32 \\
\hline Zambézia & 11.19 & 11.19 \\
\hline Manica & 10.30 & 10.83 \\
\hline Gaza & 4.70 & 6.07 \\
\hline Inhambane & 4.00 & 5.19 \\
\hline Maputo & 3.96 & 4.78 \\
\hline Maputo City & 2.86 & 4.09 \\
\hline Mozambique & 9.88 & 10.62 \\
\hline
\end{tabular}

Source: MINEDH (2015)

$<$ Table $7>$ indicates a distinctive gap of dropout rates between urban and non-urban areas. The dropout rates (10.6 percent) in non-urban areas are twice as high as in urban areas (4.41 percent). This pattern of lower dropout in urban areas is constant over the all other provinces except for within Maputo City, which as the capital city of Mozambique may not have the obvious distinction as other urban and non-urban areas.

$\langle$ Table 7〉 Dropout rate between Urban and Non-Urban

\begin{tabular}{c|c|c|c}
\hline \multirow{2}{*}{ Province } & \multicolumn{3}{|c}{ Dropout rate (\%) in 2015 } \\
\cline { 2 - 4 } & Urban & Non-Urban & $\begin{array}{c}\text { Difference } \\
\text { (Urban - Non Urban) }\end{array}$ \\
\hline Cabo Delgado & 3.2 & 14.5 & -11.3 \\
\hline Tete & 3.6 & 12.3 & -8.7 \\
\hline Niassa & 8.4 & 17.1 & -8.7 \\
\hline Sofala & 4.5 & 13.0 & -8.5 \\
\hline Zambézia & 2.7 & 10.8 & -8.1 \\
\hline Nampula & 6.5 & 12.1 & -5.6 \\
\hline Manica & 4.0 & 8.6 & -4.6 \\
\hline Gaza & 2.0 & 5.7 & -3.7
\end{tabular}




\begin{tabular}{c|c|c|c}
\hline \multirow{2}{*}{ Province } & \multicolumn{3}{|c}{ Dropout rate (\%) in 2015 } \\
\cline { 2 - 4 } & Urban & Non-Urban & $\begin{array}{c}\text { Difference } \\
\text { (Urban - Non Urban) }\end{array}$ \\
\hline Inhambane & 3.5 & 4.8 & -1.3 \\
\hline Maputo & 2.8 & 4.0 & -1.3 \\
\hline Maputo City & 3.9 & 3.4 & 0.5 \\
\hline Mozambique & 4.4 & 10.6 & -6.2 \\
\hline
\end{tabular}

Source: Education Statistics (2015)

$<$ Figure $4>$ provides the dropout patterns over the grades in the provinces. The geographic gap is still distinctive. Southern regions - Maputo City, Gaza, Inhambane, and Maputo have lower dropout rates than the rest. Dropout rates steeply hike in grade 2, 5 and 7 where all students should take a national exam to progress on to the next level. The decision for many students to drop out may be heavily impacted by having to take the national exam.

〈Figure 4〉 Dropout rate by Province

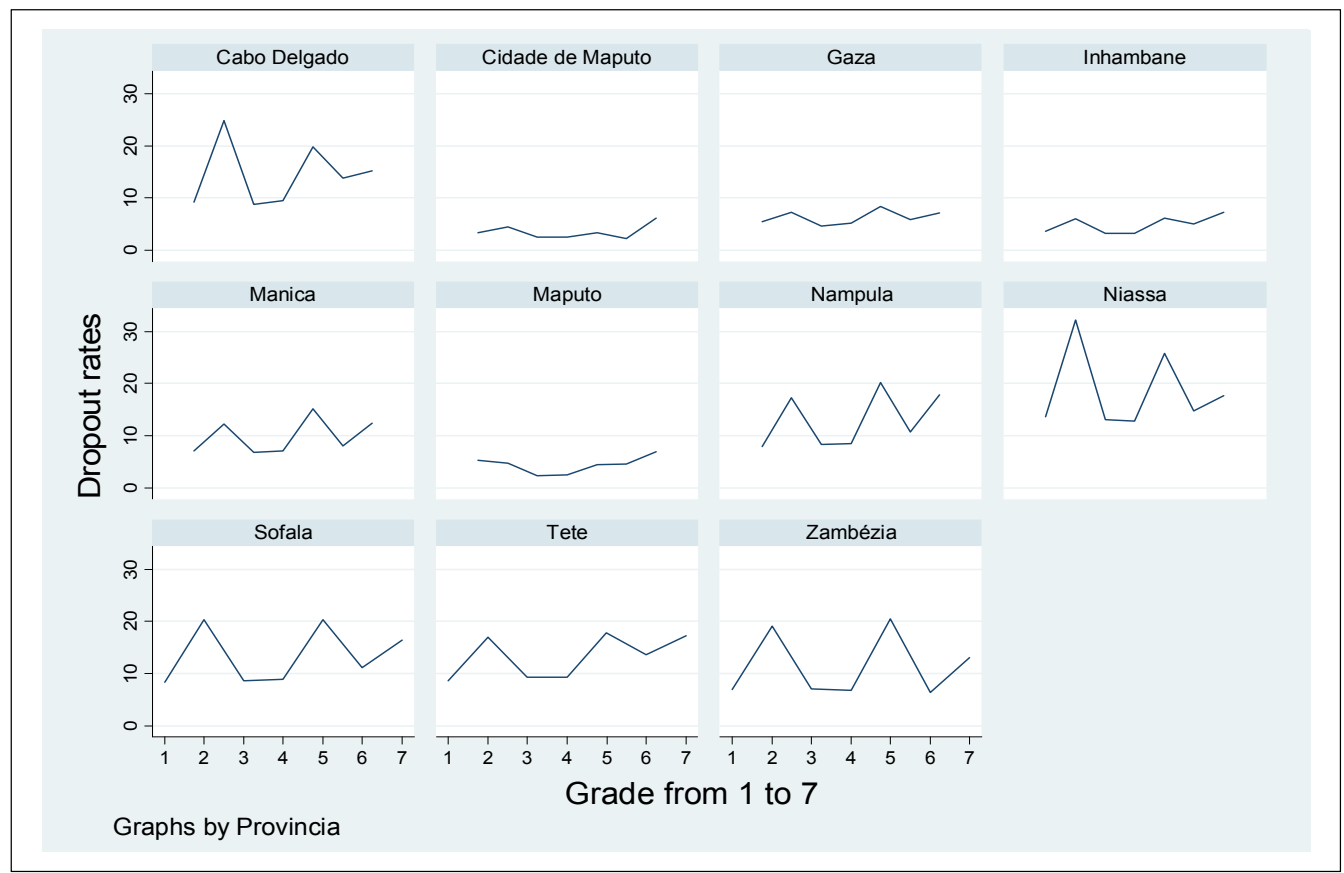

Source: MINEDH (2015) 


\section{Pass rate ${ }^{5)}$}

$<$ Table $8>$ describes the pass rate trends over grades. Due to the automatic grade promotion policy of Mozambique, the overall pass rates are high. In fact, pass rate in grade 1, 3, 4 and 6 are ignorable because the progression of pupils during the grades is based on the decision of the class teacher, while students in grade 2, 5 , and 7 should sit a national exam to gain access to next cycle in primary education or secondary education (World Bank, 2009b)

〈Table 8〉 Pass rate by Grade

\begin{tabular}{c|c|c|c|c|c|c|c|c}
\hline Grade & 1 & 2 & 3 & 4 & 5 & 6 & 7 & Average \\
\hline Total (\%) & 93.0 & 74.7 & 91.5 & 91.5 & 70.8 & 80.5 & 66.5 & 84.6 \\
\hline Male & 93.0 & 74.3 & 91.6 & 91.5 & 69.8 & 90.4 & 66.0 & 84.4 \\
\hline Female & 92.9 & 75.1 & 91.4 & 91.4 & 71.9 & 90.6 & 67.0 & 84.8 \\
\hline
\end{tabular}

Source: MINEDH (2015)

The gender gap in the pass rate is ignorable: males are 84.4 percent and females are 84.8 percent. However, looking into the provincial levels, the difference is more discernible. Interestingly, in some provinces such as Maputo City, Maputo, Gaza, and Inhambane (areas considered as educationally affluent), females are more likely to pass an exam than males. These provinces might have a more favorable environment for female's education: favorable perception of female's education and better educational infrastructure, which are proportionally beneficial to females.

〈Table 9〉 Pass rate by Gender

\begin{tabular}{c|c|c|c}
\hline \multirow{2}{*}{ Province } & \multicolumn{3}{|c}{ Pass rate (\%) } \\
\cline { 2 - 4 } & Male & Female & Total \\
\hline Maputo & 78.5 & 83.5 & 81.0 \\
\hline Cabo Delgado & 82.2 & 81.4 & 81.8 \\
\hline Cidade de Maputo & 79.3 & 84.6 & 82.0 \\
\hline Sofala & 83.6 & 83.0 & 83.3 \\
\hline Nampula & 84.0 & 82.6 & 83.4 \\
\hline
\end{tabular}

5) $\%$ of students who were taken under the evaluation or examination tests at the end of year and had notes that allow them to pass through class, including those exempted from exam (MINEDH). 


\begin{tabular}{c|c|c|c}
\hline \multirow{2}{*}{ Province } & \multicolumn{3}{|c}{ Pass rate (\%) } \\
\cline { 2 - 4 } & Male & Female & Total \\
\hline Gaza & 81.1 & 85.9 & 83.5 \\
\hline Niassa & 83.9 & 83.8 & 83.8 \\
\hline Tete & 85.3 & 85.7 & 85.5 \\
\hline Zambézia & 86.5 & 85.7 & 86.2 \\
\hline Manica & 86.1 & 86.2 & 86.2 \\
\hline Inhambane & 89.1 & 91.8 & 90.4 \\
\hline Mozambique & 84.4 & 84.8 & 84.6 \\
\hline
\end{tabular}

Source: MINEDH (2015)

\section{Repetition rate6)}

Likewise the patterns of pass rates, due to the automatic promotion policy throughout primary education, there are two distinctive patterns of repetition throughout grades: repetition of grade 2, 5, and 7, which is obviously different from the rest of the grades $(1,3,4$, and 6$)$. The first group has to take a national exam to get promoted to the next grade at the end of year and the second group doesn't. Existence of a national assessment has a close relationship with the repetition rates.

〈Table 10〉 Repetition rate by Grade

\begin{tabular}{c|c|c|c|c|c|c|c|c}
\hline Grade & 1 & 2 & 3 & 4 & 5 & 6 & 7 & Average \\
\hline Total & 3.0 & 8.9 & 4.2 & 4.2 & 11.7 & 3.5 & 12.1 & 6.2 \\
\hline Male & 3.1 & 9.3 & 4.3 & 4.4 & 12.7 & 3.7 & 12.7 & 6.6 \\
\hline Female & 3.0 & 8.4 & 4.1 & 4.0 & 10.7 & 3.2 & 11.3 & 5.9 \\
\hline
\end{tabular}

Source: MINEDH (2015)

Female students are slightly less likely to repeat a grade than male students. The female repetition rates in Maputo City, Maputo, Gaza, and Inhambane are much lower than those of males. The geographical gaps are much less than other educational indicators such as dropout and overage rates (<Table $11>$ ). Interestingly, Maputo and Maputo City, which to be believed to have better quality education shows higher

6) $\%$ of students repeat a grade 
level of repetition. The probable explanations are a large amount of flow-in of migrants from other regions: being there, whether to seek economic opportunities and more rigid school/student management practices.

〈Table 11〉 Repetition Rate by Gender and Province

\begin{tabular}{c|c|c}
\hline Province & Male & Female \\
\hline Niassa & $4.3 \%$ & $4.1 \%$ \\
\hline Cabo Delgado & $6.1 \%$ & $4.3 \%$ \\
\hline Sofala & $4.8 \%$ & $4.3 \%$ \\
\hline Tete & $5.1 \%$ & $4.4 \%$ \\
\hline Nampula & $5.0 \%$ & $5.0 \%$ \\
\hline Zambézia & $5.8 \%$ & $5.5 \%$ \\
\hline Manica & $6.6 \%$ & $6.4 \%$ \\
\hline Gaza & $6.5 \%$ & $6.4 \%$ \\
\hline Inhambane & $9.7 \%$ & $6.9 \%$ \\
\hline Maputo & $11.4 \%$ & $7.9 \%$ \\
\hline Cidade de Maputo & $11.8 \%$ & $8.9 \%$ \\
\hline Mozambique & $6.6 \%$ & $5.9 \%$ \\
\hline
\end{tabular}

Source: MINEDH (2015) 


\section{Conclusion}

We examined the four key educational indicators - overage, dropout, pass and repetition rates extracted from EMIS data. The results are echoing the findings of recent studies. More than half of students in a grade are overage which bodes ill for educational outcomes in school. Only three in ten students in the same cohort can reach grade 7 due to the unduly high dropout rate in primary education.

Notably, dropout, pass and repetition rates are deteriorating at grade 2, 5, and 7, where the national exams in each grade may affect the parent's decisions regarding school attendance. The mechanisms surrounding the national exams are not explored yet, so further research is needed to understand how it affects the educational practices in school. From the gender perspective, neither males nor females are discriminately excluded from access to quality of education. Both males and females are equally disadvantaged by poor quality of education. However, we found out there are significant differences between geographical regions and urban and non-urban areas. The educational gaps have been widening.

Mozambique has achieved remarkable progress in terms of education assess. Thanks to this, more students than ever before are attending classrooms with textbooks and blackboards. However, the increase of enrollment rates has stagnated in recent years, to make matters worse, the quality of education is gradually deteriorating. "Education for all" is still a valid claim in particular for developing countries suffering from low educational attainment, but as seen previously, it can be a lost opportunity for the future of Mozambique without quality education.

Thus, the Mozambique government and its development partners are called on to make a concerted effort to reverse harmful trends in primary education. Reducing late entry in school and ensuring learning environment should be paid more attention for development partners in planning their future assistance and interventions. 


\section{〈References〉}

EPDC. 2014. "National Education Profile 2014 Update: Mozambique," avaliable at http://www.epdc.org/sites/default/files/documents/EPDC\%20NEP_ Mozambique.pdf. (accessed on May $7^{\text {th }}, 2017$ )

MINEDH. 2012. “Education Strategic Plan 2012-2016,” available at http://www. mec.gov.mz/PROGS/Pages/plano-estrategico-educacao.aspx. (accessed on May $3^{\text {rd }}$, 2017)

. 2015. "Education Statistics Annual School Survey 2015 General

Education and Teacher Training," available at http://www.mined.gov.mz/DN/ DIPLAC/Pages/Levantamento-Escolar-2015.aspx. (accessed on May $3^{\text {rd }}$, 2017)

. 2016. "Education Statistics Annual School Results 2015 General Education and Teacher Training," available at http://www.mined.gov.mz/DN/DIPLAC/ Pages/Aproveitamento-Escolar-2015.aspx. (accessed on May $3^{\text {rd }}, 2017$ )

Passos, A., Nahara, T., Magaza, F., \& Lauchande, C. 2005. "The SACMEQ II project in Mozambique: a study of the conditions of schooling and the quality of education." Harare, Zimbabwe: SACMEQ.

Ribeiro, C. 2007. "Educational decentralization in Mozambique: a case study in the Region of Nampula." School Decentralization in the Context of Globalizing Governance, pp.159-174.

Schulz, E. M., R. Toles, W.K. Rice, I. Brauer, \& J. Harvey. 1986. "The Association of Dropout Rates with Student Attributes." San Francisco: American Educational Research Association.

UNESCO. 2012. "World Data on Education 7th edition 2010/2011," available at http://www.ibe.unesco.org/en/document/world-data-education-seventhedition-2010-11. (accessed on May $2^{\text {nd }}, 2017$ ).

UNICEF. 2014. "UNICEF Annual Report 2014 Mozambique” retrieved from https://www.unicef.org/about/annualreport/.../Mozambique_Annual_Repor t_2014.pdf. (accessed on April 27 ${ }^{\text {th }}, 12017$ ).

. 2017. "2017 Education Budget Brief,” available at http://budget. unicef. org.mz/briefs/2017/UNICEF_BB2017_Education_EN.pdf. (accessed on August 


$$
\left.30^{\text {th }}, 2017\right) \text {. }
$$

World Bank. 2009a. Abolishing school fees in Africa: lessons from Ethiopia, Ghana, Kenya, Malawi, and Mozambique. Development practice in education. Washington, DC: World Bank, available at http://documents.worldbank.org/ curated/en/780521468250868445/Abolishing-school-fees-in-Africalessons-from-Ethiopia-Ghana-Kenya-Malawi-and-Mozambique (accessed

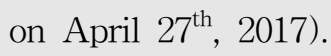
. 2009b. "Mozambique: Student Assessment. Systems Approach for Better Education Results (SABER) country report; 2009.” Washington, D.C., available at http://hdl.handle.net/10986/17699 (accessed on May $7^{\text {th }}$, 2017).

2015. Mozambique service delivery indicators. Mozambique service delivery indicators brief; education. Washington, D.C.: World Bank Group, available at http://documents.worldbank.org/curated/en/287341468181503193/ Mozambique-service-delivery-indicators. (accessed on May $7^{\text {th }}, 2017$ ). 